\title{
IN MEMORIAM \\ ACADEMIC MOMIR POLENAKOVIC, PEDIATRIC NEPHROLOGY, RARE DISEASES AND PUBLISHING IN MACEDONIA
}

\author{
Velibor Tasic, Zoran Gucev
}

University Pediatric Clinic, Medical Faculty Skopje, N Macedonia

Corresponding author: Prof. Velibor Tasic, MD, PhD, University Children's Hospital, 17 Vodnjanska, 1000 Skopje, R. N. Macedonia; Tel. + 389757891 05, e-mail: vtasic2003@gmail.com;

The death of Professor Momir Polenakovic is a major loss for Macedonian medicine and science. Professor Polenakovic was a great contributor in paediatric nephrology. His style was civility, respect, and kindness. As a young and enthusiastic doctor, he implemented percutaneous renal biopsy and immunofluorescent analysis of the kidney tissue and founded the laboratory for immunonephrology at the Clinic for Nephrology. He established an active and long-standing collaboration with the Department of Pediatric Nephrology at the Children's Hospital initially with Dr. Radmila Kotevska, Bojka Grceva and consequently with younger colleagues. This colaboration was further enhanced with to the Institute of Pathology at the Medical School with Prof. Grozdanov and Mrs. Roganavic, who implemented electronomicroscopy. Renal biopsy was an important and often decisive method in the kidney diseases investigation in children. Dr. Polenakovic's favourite topic was membranous nephropathy. In adult patients, its aetiology was an idiopathic one, while in children it was associated with HBV infection.

His great interest in pediatric nephrology originated from his stays and cooperation with well-known nephrologists from Guy's Hospital. John Stewart Cameron was a leading adult nephrologist at Guy's Hospital, but he was also a founder of the Department of Pediatric Nephrology at the same hospital. Sir Cyril Chantler later undertook the chair of pediatric nephrology. This adult-pediatric cooperation persisted, and many scholars remember Prof. Polenakovic's lessons, given at the pediatric nephrology department. Prof. Polenakovic implemented this model in Skopje. He did overcome the competition between adult and pediatric nephrologists and encouraged cooperation and an open exchange of knowledge, experience, and facilities.

Prof. Polenakovic organized numerous nephrological congresses, symposia, and meetings, but he always made sure that pediatric topics were represented and paediatricians were welcome and honoured guests. He contacted pediatric nephrologists from abroad, but also all prominent pediatric nephrologists from the former Yugoslav Republics (Prof. Milana Popovic Rolovic, Prof. Angelina Cvoric, Prof. Istok Jaksa, Prof. Danica Batinic, Prof. Esma Cemerlic Zecevic and others).

Prof. Polenakovic professionally supported the development of pediatric nephrology in Macedonia, open consultation regarding patients, and he was often selflessly sharing his experience with others. He was also a strong proponent of scientific research. He mentored a pediatric doctoral thesis related to the clinical, biological, and prognostic aspects of post-streptococcal glomerulonephritis, from which four articles originated [1-4]. 
Prof. Polenakovic was characterized by a pleasant personality and clear communication skills. We paediatricians had a teacher, from whom we learned so much. He was beloved and highly respected in the Yugoslavian pediatric nephrology community. He stimulated international cooperation and projects. For him, prevention in nephrology was extremely important, and it starts at the earliest age (foetal programming of adult health) $[5,6]$. He also understood the importance of genetic analysis in nephrology for early diagnosis, prevention, and personalized treatment $[7,8]$.

His activities in publishing have also been remarkable and impactful [10-12]. Prof. Polenakovic had an early understanding of how frequent, rare diseases are. Between 2011 and 2019, he assisted in organizing six meetings on rare diseases, attended by some of most prestigious scholars and scientists of Europe [13-17]. The meetings resulted in international projects (ICGEB), important publications [18-29], increased social awareness for the rare diseases, and, finally, the successful treatment of some patients with rare diseases with specific, and often, very expensive medications. The rare diseases community (medical professionals, patient organizations and patients) will sorely miss his civility, kindness, and good will.

Requiescat in pace.

\section{REFERENCES}

1. Tasic V, Polenakovic M.Acute poststreptococcal glomerulonephritis following circumcision. Pediatr Nephrol. 2000 Dec; 15(3-4): 274-5.

2. Tasic V,Polenakovic M. Occurrence of subclinical post-streptococcal glomerulonephritis in family contacts. J Paediatr Child Health. 2003 Apr; 39(3): 177-9.

3. Tasic V, Polenakovic M, Cakalarovski K, Kuzmanovska D.Progression of crescentic poststreptococcal glomerulonephritis to terminal uremia twelve years after recovery from an acute episode.Nephron. 1998 Aug; 79(4): 496.

4. Tasic V, Polenakovic M. Thrombocytopenia during the course of acute poststreptococcal glomerulonephritis. Turk J Pediatr. 2003 AprJun; 45(2): 148-51.

5. Tasic V, Janchevska A, Emini N, Sahpazova E, Gucev Z, Polenakovic M. Chronic kidney disease - pediatric risk factors. Pril (Makedon
Akad Nauk Umet Odd Med Nauki). 2016; 37(1): 9-13.

6. Polenakovic M, Gucev Z, Tasic V. Kidney diseases in children - early diagnosis and prevention. Pril (Makedon Akad Nauk Umet Odd Med Nauki). 2016; 37(1): 5-7

7. Tasic V, Gucev Z, Polenakovic M. Steroid Resistant Nephrotic Syndrome-Genetic Consideration. Pril (Makedon Akad Nauk Umet Odd Med Nauki). 2015; 36(3): 5-12.

8. Efremov D, Polenakovic M. ICGEB Workshop on Next Generation Diagnostics, 22/03/201824/03/2018, Macedonian Academy of Sciences and Arts, Skopje, Republic of Macedonia. Pril (Makedon Akad Nauk Umet Odd Med Nauki). 2018 Dec 1; 39(2-3): 137-142.

9. Tasic V, Lozanovski VJ, Danilovski D, Laban N, Pop-Jordanova N, Polenakovic M, Gucev ZS. Rare diseases with renal involvement in the Republic of Macedonia. Prilozi. 2011; 32(1): 55-67.

10. Gucev Z, Polenakovic M. Is impact factor necessary for "Prilozi (Contributions)" and Macedonia? Prilozi. 2013; 34(2): 5-9.

11. Polenakovic M, Gucev Z. Publishing integrity and good practices in editing in biomedicine. Prilozi 2014; 35(3):11-6.

12. Polenakovic M, Pop-Jordanova N, Gucev Z.50 Years of the Macedonian Academy of Sciences and Arts 1967-2017 and 48 Years of Publishing the Journal Prilozi (Contributions) of MASA. Prilozi (Makedon Akad Nauk Umet Odd Med Nauki). 2017 Dec 1; 38(3): 5-8.

13. Gucev ZS, Tasic V, Polenakovic M. On rare and "super-rare" diseases: an insight from the Republic of Macedonia. Prilozi. 2011; 32(1): 7-11.

14. Gucev Z, Tasic V, Polenakovic M. Meeting Report: Rare disease in south-eastern Europe, 15-17 November 2012, Skopje, Republic of Macedonia. Prilozi. 2012; 33(2): 279-81.

15. Gucev Z, Tasic V, Polenakovic M. Meeting Report: Rare disease in south-eastern Europe, 15-17 November 2012, Skopje, and Republic of Macedonia. Prilozi. 2012; 33(2): 279-81.

16. Gucev Z, Tasic V, Polenakovic M. 4th Rare Disease South Eastern Europe (See) Meeting Skopje, Macedonia (November 14th, 2015). Prilozi (Makedon Akad Nauk Umet Odd Med Nauki). 2015; 36(3): 151-6.

17. Gucev Z, Tasic V, Polenakovic M. Prilozi (Makedon Akad Nauk Umet Odd Med Nauki). 5th Rare Disease South Eastern Europe (SEE) Meeting, Skopje, Macedonia (November 15th, 2016). 2017 Mar 1; 38(1): 119-123. 
18. Laban NB, Tasic VB, Danilovski D, Polenakovic M, Gucev ZS. Severe scoliosis, torticollis and short stature in a woman with Wildervanck Syndrome (WS). Prilozi. 2015; 36(1): 209-11.

19. Gucev Z, Tasic V, Plaseska-Karanfilska D, Konstantinova MK, Stamatova A, Dimishkovska M, Laban N, Polenakovic M. LHX4 Gene Alterations: Patient Report and Review of the Literature. Pediatr Endocrinol Rev. 2016 Jun;13(4): 749-55. Review.

20. Tasic V, Janchevska A, Emini N, Sahpazova E, Gucev Z, Polenakovic M. Chronic kidney disease - pediatric risk factors. Prilozi (Makedon Akad Nauk Umet Odd Med Nauki). 2016; 37(1): 9-13.

21. Dimishkovska M, Kotori VM, Gucev Z, Kocheva S, Polenakovic M, Plaseska-Karanfilska D. Novel Founder Mutation in FANCA Gene (c.3446 3449dupCCCT) Among Romani Patients from the Balkan Region. Balkan Med J. 2018 Jan 20;35(1):108-111

22. Kostovski M, Tasic V, Laban N, Polenakovic M, Danilovski D, Gucev Z. Obesity in Childhood and Adolescence, Genetic Factors. Prilozi (Makedon Akad Nauk Umet Odd Med Nauki). 2017 Dec 1; 38(3): 121-133.

23. Tasic V, Gucev Z, Polenakovic M. Rare Renal Disease in Macedonia - An Update. Prilozi (Makedon Akad Nauk Umet Odd Med Nauki). 2017 Dec 1; 38(3): 63-69.

24. Kostovski M, Gucev Z, Tasic V, Polenakovic M.Parameters of Metabolic Syndrome in Obese Children and Adolescents. Prilozi (Makedon Akad Nauk Umet Odd Med Nauki). 2018 Jul 1; 39(1): 105-114.
25. Salihu S, Tosheska K, Cekovska S, Gucev Z, Polenakovic M, Tasic V.Low Molecular Weight Proteinuria in Children with Distal Renal Tubular Acidosis. Pril (Makedon Akad Nauk Umet Odd Med Nauki). 2018 Jul 1; 39(1): 91-95.

26. Janchevska A, Gucev Z, Tasic V, Polenakovic M.Homeostasis Model Assessment - Insulin Resistance and Sensitivity (HOMA-IR and IS) Index in Overweight Children Born Small for Gestational Age (SGA). Prilozi (Makedon Akad Nauk Umet Odd Med Nauki). 2018 Jul 1; 39(1): 83-89.

27. Gucev Z, Tasic V, Bogevska I, Laban N, Saveski A, Polenakovic M, Plaseska-Karanfilska D, Komlosi K, Winter J, Schweiger S, Nishimura G, Spranger J, Bartsch O.Heterotopic ossifications and Charcot joints: Congenital insensitivity to pain with anhidrosis (CIPA) and a novel NTRK1 gene mutation. Eur J Med Genet. 2020 Jan; 63(1): 103613.

28. Gucev ZS, Tasic VB, Saveski A, Polenakovic MH, Laban NB, Zechner U, Bartsch O.Tissuespecific mosaicism in a patient with RubinsteinTaybi syndrome and CREBBP exon 1 duplication. Clin Dysmorphol. 2019 Jul; 28(3): 142-144.

29. Gucev Z, Tasic V, Plaseska-Karanfilska D, Dimishkovska M, Laban N, Bozinovski Z, Kostovski M, Saveski A, Polenakovic M, Towler OW, Shore EM, Kaplan FS.Severe digital malformations in a rare variant of fibrodysplasia ossificans progressiva. Am J Med Genet A. 2019 Jul; 179(7): 1310-1314. 